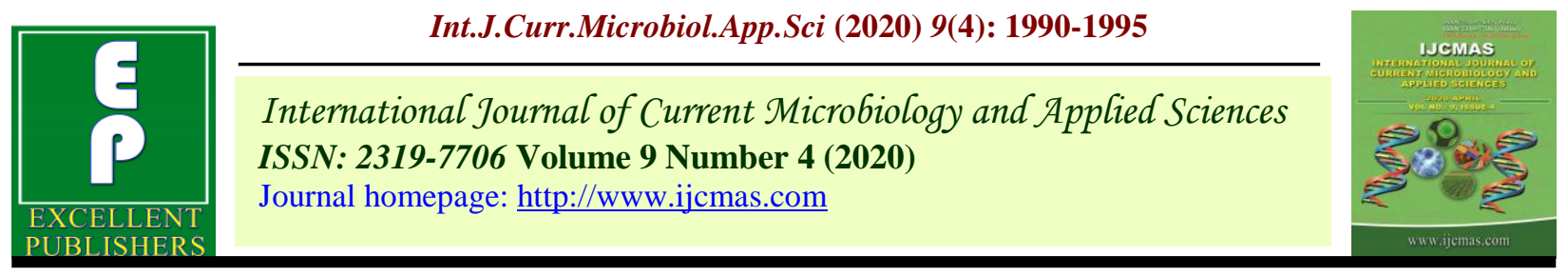

Original Research Article

https://doi.org/10.20546/ijcmas.2020.904.238

\title{
Genotype X Environment Interaction and Stability Analysis in Pigeonpea [Cajanus cajan (L.) Mill sp.]
}

\author{
P. R. Patel*, Manish Sharma, M. P. Patel and P. T. Patel \\ Pulses Research Station, S. D. Agricultural University, S.K.Nagar-385506, Gujarat, India \\ *Corresponding author
}

\begin{tabular}{|l|}
\hline Ke y w o r d s \\
Stability, \\
Genotypes, \\
Environment \\
\hline Article Info \\
$\begin{array}{l}\text { Accepted: } \\
\text { 15 March } 2020 \\
\text { Available Online: } \\
10 \text { April } 2020\end{array}$ \\
\hline
\end{tabular}

\section{A B S T R A C T}

Twenty one pigeonpea genotypes were evaluated at four environments during kharif 2018-19, to study genotype $\times$ environment interaction for yield and its contributing traits. The experiment was laid out in randomized block design with three replication. Analysis of variance in each environment and on a pooled basis expressed a significant difference among genotypes for yield and yield contributing characters except for branches per plant and seeds per pod. Environment (linear) interaction component was significant for all the traits. Highly significant genotypeenvironment interaction indicated differential response of the genotypes to the environmental changes. The variance due to pooled deviation (nonlinear) was highly significant for all the characters except for pods per plant and seeds per pod which reflect considerable amount of genetic diversity in the material. The genotypes GJP 1606 and GJP 1601 were high yielding and stable across environments for seed yield per plant.

\section{Introduction}

Pigeonpea (Cajanus cajan (L.) Millsp.) is the important grain legume which occupies a major place in dietary requirement. It is cultivated in varied agro climatic conditions ranging from moisture stress and input starved conditions to irrigated conditions. In India, this crop occupies 4.43 million hectare area with total production of 4.25 million tones (Directorate of Economics and Statistics), where as in the world, it occupies an area of 7.02 million hectare with total production 6.80 million tones having productivity of $969 \mathrm{~kg} / \mathrm{ha}$ respectively (FAO STAT). Gene action and phenotypically stable genotypes are of great importance, because the environmental conditions vary from region to region. The stability is the consistency in performance of a variety over a wide range of environments (Singh and Chaudhary, 1985). Genotype may react to variable environments in such a way that its development is buffered against 
environmental variations and more or less similar phenotype is produced under varying environmental conditions. Thus, stability depends upon the relative insensitivity of a genotype to varied environments. Wide adaptation to the particular environment and consistence performance of recommended varieties/ hybrids are very important for successful cultivation of pigeonpea. Pigeonpea breeders look forward for widely adopted genotypes responsive to input intensive as well as input deficient agriculture in order to enhance production and productivity of the crop. With this back ground the present study was undertaken under at three different locations to identify stable genotypes of pigeonpea for seed yield and other component.

\section{Materials and Methods}

Experimental material for the present study consists of twenty one pigeonpea genotypes grown in randomized complete block design with 3 replications during kharif 2018-19 at Sardarkrushinagar, Junagadh, Navsari and Vadodara. Each plot consisted of six rows of $4 \mathrm{~m}$ length with spacing of $60 \times 20 \mathrm{~cm}$. All recommended agronomic practices were followed to raise the normal crop at each location. Observations were recorded on five randomly selected plants of each genotype in each replication for various characters i.e. plant height $(\mathrm{cm})$, number of branches per plant, number of pods per plant, pod length (cm), Number of seeds per pod, 100-seed weight $(\mathrm{g})$, seed yield per plant $(\mathrm{g})$, Days to flower on the basis of 50 per cent plants of each genotype flowered and days to maturity, on the basis of 80 per cent plants of each genotype matured were recorded. The replication wise mean value of each genotype for various characters was used for statistical and genetical analysis. The statistical analysis for $\mathrm{G} \mathrm{X} \mathrm{E} \mathrm{interaction} \mathrm{and} \mathrm{stability} \mathrm{parameters}$ was carried out according to the method of
Eberhart and Russell (1966). The following assumptions according to Finley and Wilkinson (1963) and Eberhart and Russell (1966) were considered for finding stable genotype for different characters. (i) above average yield in all locations, (ii) regression coefficient (bi) is near ' 1 '( $(\mathrm{bi}=1)$ and (iii) deviation from regression $\left(\mathrm{s}^{2} \mathrm{di}\right)$ is as small as possible to ' 0 ' $\left(\mathrm{s}^{2} \mathrm{di}=0\right)$. Genotype superior for favorable environment having higher than average mean, significant bi above the unity and least $s^{2}$ di $\left(s^{2} \mathrm{di}=0\right)$, whereas for poor environment having higher than average mean, significant bi lower the unity and least $\mathrm{s}^{2} \mathrm{di}\left(\left(\mathrm{s}^{2} \mathrm{di}=0\right)\right.$.

\section{Results and Discussion}

Pooled mean sum of squares values for different quantitative characters over three environments (Table 1) showed that the mean differences among genotypes and environments were highly significant indicating that genotypes possessed significant amount of variation for these traits confirming random and variable nature of environments selected, which influenced the expression of these traits. These results were similar to the earlier findings of Patel et al., (2009). All the traits showed significant differences due to environment, indicating that all the locations were highly variable. Partitioning of this variation into linear and non-linear components exhibited that mean square due to environment (linear) were highly significant for important traits under study. It suggested that environments were random and different and they reflected the expression of these traits and this variation could have arisen due to the linear response of the regression of the cultivars to the environments. The G x E (Linear) interaction revealed significant differences for pods per plant, days to maturity, branches per plant and hundred seed weight indicating that phenotypic performance of the genotypes was 
predictable for these characters. The same trend was also observed by Singh et al., (2015).

Phenotypic stability was estimated on the basis of three parameters namely; mean performance over years (x), regression coefficient (bi) and deviation from regression $\left(\mathrm{S}^{2} \mathrm{di}\right)$ as suggested by Eberhart and Russell (1966). The estimation of stability for yield and its attributing traits is depicted in Table 2. High value of regression (bi>1) indicates that the variety is more responsive to the rich input environments, whereas low value of regression coefficient $(\mathrm{bi}<1)$ indicates that the variety may be suitable in poor environment. Based on stability parameters the genotypes viz., SKNP 1413, BDN 2 and GJP 1715 were found to be stable for days to $50 \%$ flowering as indicated by non significant deviation from regression and regression coefficient $(\mathrm{bi}=1)$. The genotypes AAUVT 15-13, GJP1508 and GJP 1606 showed low mean, bi>1 and less deviation from regression were identified as desirable and stable for days to maturity. The similar results were also reported by Reddy et al., (2011). Genotypes viz., SKNP 1614, AAUVT 15-13 and GJP 1303 had highest mean number of pods among 21 tested genotypes while genotypes BP 15-11, AAUVT 13-20 and BP 17-11 recorded highest pod length. Genotypes BP 17-11, GJP 1 and GJP 1721 showed highest test weight. These characters are important as they contribute directly towards final product i.e. grain yield.

The genotype GJP 1606 showed highest mean performance for grain yield per plant, with regression coefficient (bi=0.996) and non significant deviation from regression. This indicated that this genotype is stable across all the environments and it can be recommended for cultivation in variable conditions. Further genotype AAUVT 15-13 and Genotype SKNP 1614 showed high mean grain yield with regression coefficient greater than one indicating suitability of these genotypes to specific environments. Similar results were also observed by Sreelakshmi et al., (2010).

Table.1 Pooled MSS values for different quantitative characters over three environments

\begin{tabular}{|l|l|l|l|l|}
\hline Characters & $\begin{array}{l}\text { Genotypes X } \\
\text { Environment }\end{array}$ & Genotypes & Environments & $\begin{array}{l}\text { Genotypes X } \\
\text { Environment (Lin.) }\end{array}$ \\
\hline Days to 50 \% flowering & $12.735^{* *}$ & $56.487^{* *}$ & $1,378.663^{* *}$ & 8.041 \\
\hline Days to 80 \% maturity & $21.739^{* *}$ & $43.985^{*}$ & $5,646.175^{* *}$ & $42.237^{* *}$ \\
\hline Plant height (cm) & 78.475 & $969.340^{* *}$ & $13,071.100^{* *}$ & 75.411 \\
\hline Branches per plant & 1.037 & 1.304 & $386.861^{* *}$ & $1.448^{*}$ \\
\hline Number of pods per plant & 412.792 & $465.796^{* *}$ & $18,595.833^{* *}$ & $894.329 * *$ \\
\hline Pod length (cm) & 0.096 & $0.342^{* *}$ & $2.957^{* *}$ & 0.075 \\
\hline Number of seeds per pod & 0.129 & $0.283^{*}$ & $0.879 * *$ & 0.061 \\
\hline 100 seed weight (g) & $0.226^{* *}$ & $2.581^{* *}$ & $6.819^{* *}$ & $0.318^{*}$ \\
\hline Yield kg per Ha. & $70,073.415^{*}$ & $211,051.608^{* *}$ & $8,817,934.166^{* *}$ & $40,194.585$ \\
\hline
\end{tabular}


Table. 2 Mean stability parameters in 14 advanced genotypes of pigeon pea

\begin{tabular}{|c|c|c|c|c|c|c|c|c|c|}
\hline Traits & Days to 5 & $\%$ flowe & & Days to 8 & \% matu & & Plant hei & ht (cm) & \\
\hline Genotypes & Mean & bi & $\mathrm{S}^{2} \mathrm{di}$ & Mean & bi & $\mathrm{S}^{2} \mathrm{di}$ & Mean & bi & $\mathrm{S}^{2} \mathrm{di}$ \\
\hline VAISHALI (C) & 116.500 & 0.795 & 4.176 & 165.417 & 0.831 & 23.118 & 158.333 & 0.824 & 145.009 \\
\hline AAUVT 13-35 & 114.667 & 0.990 & 2.062 & 165.750 & 1.252 & 1.190 & 175.017 & 0.904 & -4.307 \\
\hline GJP 1606 & 120.833 & 1.279 & 16.639 & 171.917 & 1.025 & 1.350 & 173.750 & 0.901 & -19.304 \\
\hline SKNP 1413 & 118.167 & 1.018 & 1.183 & 170.250 & 0.975 & -1.447 & 172.950 & 1.124 & -2.887 \\
\hline AAUVT 15-06 & 114.917 & 1.113 & 4.928 & 165.167 & 1.307 & 7.646 & 169.767 & 1.191 & -4.594 \\
\hline AGT 2 (C) & 107.750 & 1.043 & 24.106 & 161.583 & 1.324 & 13.377 & 170.983 & 1.351 & -13.534 \\
\hline GJP 1508 & 116.083 & 1.057 & 14.173 & 169.583 & 1.018 & -0.891 & 181.633 & 1.181 & 18.759 \\
\hline GJP 1 (C) & 124.583 & 1.307 & 30.082 & 169.417 & 0.375 & 6.849 & 167.433 & 1.045 & 5.482 \\
\hline SKNP 1315 & 118.167 & 1.038 & -0.100 & 168.500 & 0.834 & 7.440 & 159.067 & 0.834 & -17.317 \\
\hline GJP 1303 & 119.583 & 1.071 & 13.219 & 171.750 & 0.837 & 6.500 & 150.533 & 0.871 & 286.001 \\
\hline BDN 2 (C) & 112.667 & 1.027 & 45.252 & 167.000 & 1.166 & 18.130 & 138.217 & 0.566 & -20.624 \\
\hline AAUVT 13-20 & 115.083 & 1.316 & 1.285 & 168.833 & 1.160 & -1.555 & 177.500 & 1.088 & -19.945 \\
\hline GJP 1601 & 117.583 & 1.203 & 2.629 & 170.083 & 0.839 & 0.339 & 151.550 & 0.973 & 17.155 \\
\hline GJP 1715 & 117.917 & 1.027 & 10.288 & 167.917 & 0.805 & 1.339 & 168.583 & 0.623 & 164.548 \\
\hline SKNP 1617 & 115.333 & 0.836 & 4.734 & 165.167 & 0.993 & 28.822 & 180.800 & 1.260 & 28.189 \\
\hline SKNP 1614 & 118.583 & 0.595 & 5.314 & 166.333 & 1.132 & 11.329 & 169.267 & 1.165 & 21.681 \\
\hline AAUVT 15-13 & 113.750 & 0.551 & 9.517 & 165.583 & 1.013 & 30.571 & 177.717 & 1.132 & 132.621 \\
\hline BP 17-11 & 113.667 & 0.965 & 45.257 & 162.750 & 1.266 & 13.124 & 207.483 & 1.096 & 81.122 \\
\hline SKNP 1621 & 110.750 & 1.048 & 15.394 & 159.333 & 1.087 & 5.164 & 153.067 & 1.014 & 46.067 \\
\hline GJP 1721 & 121.417 & 0.871 & 15.431 & 170.667 & 0.697 & 3.790 & 187.033 & 1.056 & 5.576 \\
\hline BP 15-11 & 118.000 & 0.849 & 9.244 & 168.500 & 1.064 & 4.615 & 191.467 & 0.801 & 61.538 \\
\hline
\end{tabular}

\begin{tabular}{|c|c|c|c|c|c|c|c|c|c|}
\hline Traits & Numbei & branche & jer plant & Number & pods pe & lant & Pod len & (cm) & \\
\hline Genotypes & Mean & bi & $\mathrm{S}^{2} \mathrm{di}$ & Mean & bi & $\mathrm{S}^{2} \mathrm{di}$ & Mean & bi & $\mathrm{S}^{2} \mathrm{di}$ \\
\hline $\begin{array}{c}\text { VAISHALI } \\
\text { (C) }\end{array}$ & 8.117 & 0.907 & -0.408 & 191.117 & 1.292 & -172.039 & 4.588 & 0.773 & 0.048 \\
\hline AAUVT 13-35 & 9.000 & 1.148 & 0.095 & 187.967 & 1.297 & -241.729 & 5.060 & 1.292 & -0.016 \\
\hline GJP 1606 & 8.933 & 1.033 & -0.237 & 189.850 & 1.740 & -216.676 & 5.007 & 0.195 & 0.001 \\
\hline SKNP 1413 & 9.517 & 1.138 & 0.663 & 165.600 & 0.642 & -119.126 & 5.140 & 1.421 & 0.160 \\
\hline AAUVT 15-06 & 8.417 & 1.096 & 0.065 & 181.683 & 1.837 & -16.410 & 4.805 & 1.100 & 0.121 \\
\hline AGT 2 (C) & 7.983 & 0.828 & 0.618 & 190.117 & 2.215 & -75.963 & 4.711 & 1.010 & 0.006 \\
\hline GJP 1508 & 9.183 & 1.125 & -0.080 & 176.017 & 0.811 & -190.630 & 4.970 & 0.457 & 0.110 \\
\hline GJP 1 (C) & 9.500 & 1.270 & 0.632 & 188.800 & 1.389 & -51.213 & 4.948 & 1.369 & 0.118 \\
\hline SKNP 1315 & 8.633 & 0.972 & 0.078 & 177.350 & 1.630 & 408.747 & 4.956 & 1.292 & 0.006 \\
\hline GJP 1303 & 8.900 & 1.106 & 0.320 & 193.550 & 1.323 & -142.492 & 4.867 & 0.802 & 0.046 \\
\hline BDN $2(C)$ & 8.000 & 0.738 & 0.361 & 177.667 & 0.635 & 430.461 & 4.509 & 0.803 & 0.083 \\
\hline AAUVT 13-20 & 7.950 & 0.818 & 2.193 & 177.583 & 1.042 & -225.316 & 5.413 & 0.776 & -0.001 \\
\hline GJP 1601 & 8.583 & 1.007 & 0.140 & 175.000 & 0.618 & 79.862 & 4.951 & 0.525 & 0.322 \\
\hline GJP 1715 & 8.767 & 0.944 & -0.238 & 170.017 & 0.433 & -262.600 & 4.703 & 1.339 & -0.005 \\
\hline SKNP 1617 & 8.867 & 1.007 & -0.303 & 175.633 & 0.283 & -240.718 & 5.213 & 1.423 & 0.183 \\
\hline SKNP 1614 & 9.283 & 1.140 & -0.248 & 204.200 & 1.283 & -204.641 & 4.656 & 1.230 & 0.036 \\
\hline AAUVT 15-13 & 8.833 & 0.969 & -0.241 & 193.983 & 0.860 & -156.084 & 5.195 & 0.364 & 0.027 \\
\hline BP 17-11 & 7.667 & 0.771 & 0.168 & 171.100 & 0.059 & -240.579 & 5.331 & 1.963 & 0.335 \\
\hline SKNP 1621 & 8.533 & 1.001 & 0.164 & 168.300 & 0.644 & -239.271 & 4.860 & 0.946 & -0.016 \\
\hline GJP 1721 & 9.583 & 1.270 & 0.405 & 171.200 & 0.841 & -263.023 & 5.039 & 1.004 & 0.004 \\
\hline BP 15-11 & 7.967 & 0.712 & 3.865 & 164.992 & 0.125 & -43.429 & 5.736 & 0.917 & -0.012 \\
\hline
\end{tabular}




\begin{tabular}{|c|c|c|c|c|c|c|c|c|c|}
\hline \multirow{2}{*}{$\begin{array}{l}\text { Traits } \\
\text { Genotypes }\end{array}$} & \multicolumn{3}{|c|}{ Number of seeds per plant } & \multicolumn{3}{|c|}{ Test weight (g) } & \multicolumn{3}{|c|}{ Yield (kg ha $\left.{ }^{-1}\right)$} \\
\hline & Mean & bi & $\mathrm{S}^{2} \mathrm{di}$ & Mean & bi & $S^{2} \mathrm{di}$ & Mean & $\mathrm{Bi}$ & $\mathrm{S}^{2} \mathrm{di}$ \\
\hline VAISHALI (C) & 4.150 & 0.744 & -0.107 & 10.053 & 0.729 & 0.138 & $2,016.000$ & 0.659 & $42,637.109$ \\
\hline AAUVT 13-35 & 4.183 & 0.375 & -0.081 & 10.711 & 0.524 & 0.095 & $2,142.083$ & 0.828 & $-9,372.957$ \\
\hline GJP 1606 & 4.133 & 1.054 & -0.073 & 10.497 & 0.331 & 0.155 & $2,183.500$ & 0.996 & 904.355 \\
\hline SKNP 1413 & 4.467 & 1.178 & 0.003 & 10.780 & 1.199 & 0.002 & $1,719.083$ & 0.853 & $64,991.773$ \\
\hline AAUVT 15-06 & 4.167 & 1.846 & 0.065 & 10.149 & 1.542 & 0.399 & $1,932.000$ & 1.032 & $56,394.037$ \\
\hline AGT 2 (C) & 4.283 & 0.764 & -0.113 & 9.270 & 1.079 & 0.142 & $1,641.000$ & 1.052 & $-12,125.465$ \\
\hline GJP 1508 & 4.200 & 0.088 & -0.079 & 10.481 & 0.889 & -0.028 & $1,714.333$ & 0.751 & $83,303.382$ \\
\hline GJP 1 (C) & 4.533 & 3.409 & 2.205 & 11.812 & 0.076 & 0.238 & $1,809.167$ & 1.209 & $92,836.972$ \\
\hline SKNP 1315 & 4.000 & 1.236 & -0.099 & 10.721 & 2.101 & 0.240 & $1,754.167$ & 0.891 & $-2,523.852$ \\
\hline GJP 1303 & 4.000 & 0.703 & -0.101 & 10.261 & 0.940 & 0.134 & $1,897.583$ & 0.894 & $10,046.218$ \\
\hline BDN 2 (C) & 3.767 & 0.825 & -0.097 & 9.455 & 1.099 & 0.066 & $1,418.750$ & 0.937 & $9,785.240$ \\
\hline AAUVT 13-20 & 4.633 & 0.522 & -0.036 & 11.514 & 1.352 & -0.037 & $1,921.000$ & 0.950 & $273,191.676$ \\
\hline GJP 1601 & 4.133 & 0.467 & -0.074 & 9.716 & 0.861 & 0.092 & $2,097.333$ & 1.018 & $6,326.577$ \\
\hline GJP 1715 & 4.242 & 0.448 & -0.043 & 10.152 & 2.271 & 0.041 & $1,932.250$ & 1.270 & $15,435.595$ \\
\hline SKNP 1617 & 4.300 & 0.814 & -0.078 & 10.508 & 1.664 & 0.064 & $1,846.500$ & 1.206 & $42,680.865$ \\
\hline SKNP 1614 & 3.950 & 0.645 & -0.107 & 9.913 & 0.943 & 0.082 & $2,042.083$ & 1.201 & $-14,140.710$ \\
\hline AAUVT 15-13 & 4.383 & 1.057 & -0.089 & 11.413 & 0.205 & -0.037 & $2,086.583$ & 1.194 & $98,342.269$ \\
\hline BP 17-11 & 4.717 & 1.161 & -0.037 & 12.367 & 0.700 & 0.216 & $1,718.833$ & 1.054 & $202,678.353$ \\
\hline SKNP 1621 & 4.117 & 0.798 & -0.112 & 10.606 & 1.179 & 0.178 & $1,387.750$ & 0.789 & $151,700.194$ \\
\hline GJP 1721 & 4.333 & 1.067 & -0.066 & 11.753 & 0.936 & 0.487 & $2,013.583$ & 1.291 & $215,604.599$ \\
\hline BP 15-11 & 4.867 & 1.799 & -0.104 & 11.113 & 0.380 & -0.014 & $1,499.417$ & 0.926 & $62,662.989$ \\
\hline
\end{tabular}

In general, the hybrid which found stable for grain yield also depicted stability in respect of its one or more yield component. This indicated that the stability of various component traits might be responsible for observed stability of genotypes for grain yield. The chance for selection of stable genotypes could be strengthened by selection in favour of stability in some of the yield components. Grafius (1956) also suggested that the stability of yield might be due to the stability of various yield components. The mean yield of each genotype depends on the particular set of environmental conditions. It is therefore, suggested that in order to identify stable genotype, actual testing over a wide range of environments including poor and good ones would be advantageous while making selection and attention should be paid to the phenotypic stability of traits directly related to grain yield, particularly number of pods per plant, seeds per pod, days to maturity and test weight so as to achieve maximum stability for the end product i.e., grain yield in pigeonpea. From the present investigation, it may be concluded that there was no superior genotype for all the traits in all the environments. The genotype GJP 1606 was found to be stable across environments for grain yield with desirable traits such as pods per plant, pod length and test weight and can be exploited for stabilizing yield of pigeonpea in different environments.

\section{References}

Allard, R.W. and Bradshaw, A.D. (1964). Implications of genotype environmental interactions in applied plant breeding. Crop Science. 4: 503-508.

Breese, E.L. (1969). The measurement and significance of genotype environment interactions in grasses. Heredity. 24: 2744.

Eberhart, S.A. and Russell, W.A. (1966). Stability parameters for comparing varieties. Crop Science. 6: 26-40.

Finlay, K.W. and Wilkinson, G.N. (1963). 
Analysis of adaptation in plant breeding programme. Australian Journal of Agricultural Research. 14: 742-754.

Grafius, J.E. (1956). Components of yield in oats, a geometrical interpretation. Agronomy Journal. 51: 515-554.

Lerner, I.M. (1954). Genetic homeostasis. John Wiley, New York.

Levin, D.A. and Kerster, H.W. (1970). Phenotypic dimorphism and population fitness in phlox. Evolution. 24: 128-134.

Mather, K. (1943). Polygenic inheritance and natural selection. Biological Reviews. 18: 32-64.

Lewis, D. (1954). Genotype-environment interaction : A relationship between dominance, heterosis, phenotypic stability and variability. Heredity. 8: 333-356.

Paroda, R.S. and Hayes, J.D. (1971). An investigation of genotype-environment interactions on rate of ear emergence in spring barley. Heredity. 26: 157-175.

Patel P.T., Chauhan R.M., Parmar L.D. and Tikka S.B.S (2009). Phenotypic stability of yield and related traits in pigeonpea. Legume Res. 32(4): 235239.

Reddy, D. K. R., Venkateswarlu, O., Obaiah, M. C. and Siva Jyothi, G. L. (2011). Genotype x Environment interaction for grain yield and its components in red gram [Cajanus cajan (L.) Millsp]. Legume Res., 34(4): 288-291.

Saxena KB, Singh L, Gupta MD (1990) Variation for natural out-crossing in pigeonpea. Euphytica 46:143-148

Saxena, K.B. and Sharma, D. (1990). Pigeon pea genetics. In: The Pigeon pea, (Nene, Y.L., Hall, S.D. and Sheila, V.K. eds) CAB International, Wallingford, U.K., pp $137-158$.

Saxena KB, Kumar RV, Latha KM, Dalvi VA (2006) Commercial pigeonpea hybrids are just a few steps away. Indian $\mathbf{J}$ Pulses Res 19(1):7-16

Singh, J., Kumar, A. and Abdul Fiyaz R. (2015). Diversity and stability analysis for yield and component traits in Cajanus cajan under rainfed conditions. Legume Res., 38 (2): 169-173.

Singh, R.K. and Chaudhary, B.D. (1985). Biometrical Methods in Quantitative Genetic Analysis. Kalyani Publishers, New Delhi.

Sreelakshmi, Ch., Shivani, D. and Kumar C.V.S. (2010). Studies on Genotype x Environment interaction and stability analysis in white seeded pigeonpea (Cajanus cajan (L.) Millsp) genotypes. Legume Res., 33: 217-220.

Tikka SBS, Parmar LD, Chauhan RM (1997) First record of cytoplasmic genic male sterility system in pigeonpea [Cajanus cajan (L.) Millsp.] through wide hybridization. Guj Agric Univ Res J. 22(2):160-162

Uttam C., Ashok N.T., Niraj K., Saxena K.B. and Sunil C. (2014). Yield Stability in Pigeon pea Hybrids [Cajanus cajan (L.) Millsp.] Under Varying Agro-Climatic Regions. Ratar. Povrt. 51(1): 7-17.

Waddington, C.H. (1942). Canalization of development and the inheritance of acquired characters. Nature. 150: 563565.

\section{How to cite this article:}

Patel, P. R., Manish Sharma, M. P. Patel and Patel, P. T. 2020. Genotype X Environment Interaction and Stability Analysis in Pigeonpea [Cajanus cajan (L.) Mill sp.]. Int.J.Curr.Microbiol.App.Sci. 9(04): 1990-1995. doi: https://doi.org/10.20546/ijcmas.2020.904.238 